\title{
Building The Tree Inventory Application for City of East Jakarta
}

\author{
Bambang Sulistyantara ${ }^{1}$ Imawan $^{2}$, Nasirudin $^{3}$, Hendrawan $^{4}$ \\ ${ }^{\prime}$ Lecturer at Dept. Landscape Architecture Bogor Agricultural University \\ ${ }^{2,3}$ Graduate Student Bogor Agricultural University \\ ${ }^{4}$ Application Programmer \\ Email: bbsulistyantara@yahoo.co.id
}

\begin{abstract}
Trees are essential elements of an urban space. The presence of trees in urban areas is not only appreciated as physical attribute, but beyond this, it serves a fundamental function in balancing and conserving urban ecosystem. Especially in tropical countries like Indonesia which receive high levels of solar radiation, trees contribute to the protection of urban areas from the impact of excessive micro-climatic conditions. But, the presence of trees sometimes resulted in the accidents for the residences because of broken branches and human injuries. This situation leads the city to prepare a tree inventory system, which is beneficial in giving the information about tree conditions and thus the information that would be useful for tree maintenance activities. The tree inventory on application for the city of East Jakarta was built for this purpose, comprising a tree inventory and easy access to the database. The application connects the database source with the GIS map, so that the users could retrieve information for each kind of data.
\end{abstract}

\section{INTRODUCTION}

\section{a. Background}

The development of urban areas that is focused on physical construction has much more neglected urban greenery, especially on greenery of road. This is in turn affecting on the physical condition of trees, indicated by the trees indury. The lack of trees health will become a serious problem for comfort and safety of traffic users. In rainy season with storm and hurrycane, this will induce stem breaking and tree fallen down. This is why we want to monitore physical condition of trees, especially of urban roadtrees. The monitoring of trees condition involves the checking of trees induries, both caused by pest and diseases, and by mechanical induries.

In order to know the intensity of trees monitoring, it would be known some data including trees inventory, greenery facilities inventory, and the intensity of trees maintenance programs, and other related data. The problem faced by the municipal government of East Jakarta City in management of road-trees and greenery open spaces, is the lack of information of trees maintenance. The information management system for tree maintenance is the fundamental guidance which is essential for the judgement of development management of road-trees and greenery open space, due to earn the more efficient maintenance management.

\section{b. The Purposes}

The purpose of this study is to build information managament system of trees and greenery open space for the area of East Jakarta City. This information would be usefull for some reasons: (1) the availability of information of trees and greenery management which is accessable and accurate, (2) the increasing of efficiency in budget and time for monitoring and ndaintery a ce, and (3) the increasing of communication between municipal government 


\section{METHODOLOGY}

\section{a. Time and Location}

This study was conducted by observation of trees at road and some park of East Jakarta during October 2006 . The study areas comprises ca. $187.77 \mathrm{~km}^{2}$ or abot $28,37 \%$ of the area of Jakarta Metropolitan. The study location was limited for five protocol roads and two parks. The protocol roads includes: (1) Jalan Raya Bogor, (2) Jalan Maxjen Sutoyo, (3) Jalan Jenderal Ahmad Yani, (4) Jalan Raya Kalimalang, (5) Jalan Kayu Putih Raya. While the parks includes: (1) Taman Hutan Kota at Pondok Kelapa, (2) Taman Dermaga, at Duren Sawit.

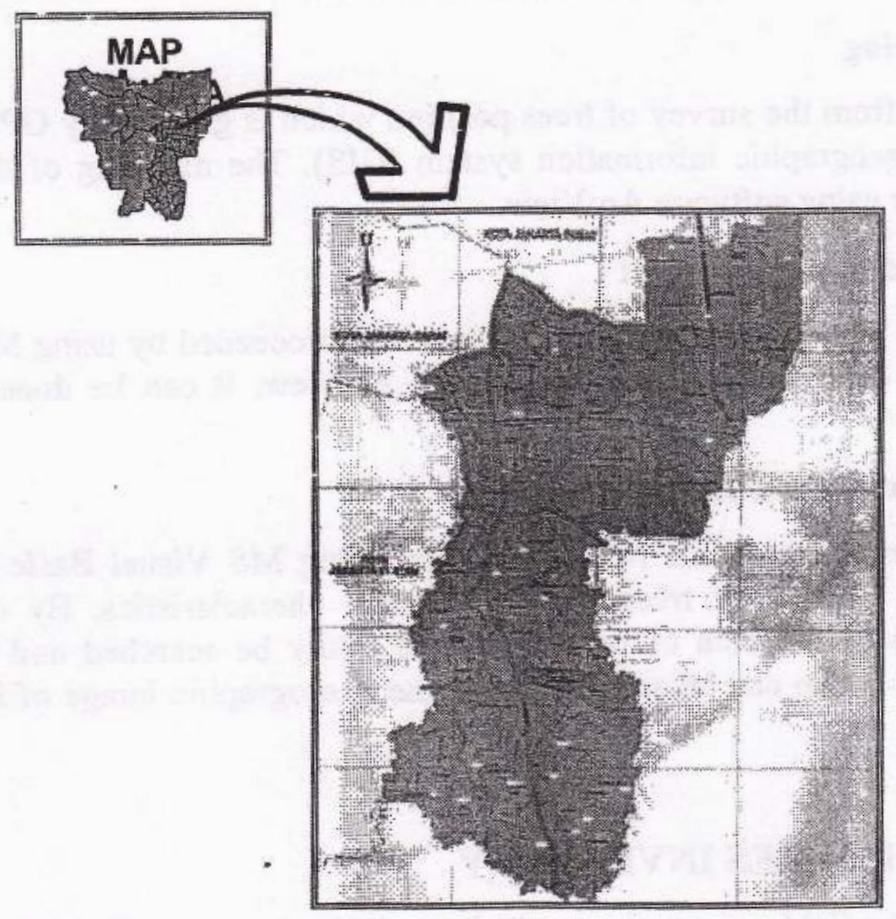

Figure 1. Study Location at East Jakarta City, Indonesia

\section{b. Facilities}

Materials. The materals needed for the study includes: (1) Topograhic map of East Jakarta, (2) Landsat TM-7, (3) Data of managament of trees and greeneries, and (4) Trees at sites.

Tools. Some softwares were used for the study, includes: (1) Arc View GIS v 3.2 3D Spatial Analyst Extentions; (2) Microsoft Access; (3) Visual Basic 6. While the hardware used includes: PC Pentium P4 $1800 \mathrm{MHz}$ SSE Ready, DDR RAM $256 \mathrm{MB}$. The tools needed for survey includes:(1) GPS Garmin Etrex Vista, (2) Compas of Suunto, (3) Digital camera, (4) Abney level, and (5) Roll-meter.

\section{c. Data Collecting}

The method for data collection condected for this study comprises of survey and reference study. The survey of tree condition was conducted by suveying along the tree condtion at study location, while the reference study was conducted due to find the information of trees maintenance standard applied at East Jakarta. In general, the study was condycted int four steps: (1) trees data and management data collection (2) mapping of trees Ha. (3) mahigament of trees database, (4) user interface development. 
- Trees data and management data collecting

- Tree Physical Inventory. Inventory on trees includes 5 aspects: (1) diameter at breast height (DBH), (2) tree height, (3) canopy weidth, (4) canopy form (symetrical of canopy), and (5) location of trees (UTM).

- Trees Health Valuation. Tree health valuation was done based on three kinds of indury factors, i.e. (1) pest and disease, (2) machanic, (3) technique Then the value of trees indury was classified into four categories (modification of Grey and Deneke, 1978): (1) Category 1 (best) with the indury up to $15 \%$, (2) Category 2 (good) with the indury $15-30 \%$, (3) Category 3 (bad) with the indury $30-50 \%$, and (4) Category 4 (worse) with the indury more than $50 \%$ or dead.

\section{- Trees Mapping}

Data earned from the survey of trees position which is grasped by GPS, was inputted for program of geographic information system (GIS). The mapping of this UTM data was conducted by using software ArcView.

\section{- Trees Database Management}

Data of trees including the number and text was proceeded by using MS Access. And, to make a link data between MS Access and Arcview, it can be done by operating MS Visual Basic 6.

\section{- User Interface Development}

The user interface program was built up by using MS Visual Basic 6 , comprising the geographical position of trees and its physical characteristics. By operating the user interface project, the data of trees would be easily be searched and retrieved, and the location on the map can be seen. Besides, the photographic image of individual tree can also be seen.

\section{RESULT OF TREES INVENTORY}

Based on the field survey, the result showed that there was the data of trees population along the location of study comprised of 4227 trees. The trees were composted of 42 species, which was distributed unevenly. Among those trees, there was $14.9 \%$ of trees that is in bad to worse condition, or the trees in good to best condition was about $85.1 \%$. The trees were distributed in seven location (of five roads and two parks). The location at J1. Mayjen Sutoyo and Jl. Kali Malang contributed large sumber of trees with bad condition. The indury of trees usually was mostly caused by vandalism activity. The form of vandalism involved by painting, push the trees with nails, for hanging commercial items, and some by cutting branches in order to build kiost behind. This situation leads to have to strengthen the regulation to maintain trees against vandalism, especially for all trees located near commercial activities.

The distribution of trees at seven location and those health condition is described as below:

\section{a. Jl. Raya Bogor}

Trees were distributed along west and east sides of road, making a line of trees with the nort-south orientation, from the point of Pasar Rebo fly-over to Cililitan Shopping Center. The number of trees is 436 composted of 19 species, involving at west-side 348 trees and ateast-side 88 trees. Among the trees, there was 92 trees in bad condition and 4 trees worse.

\section{b. Jl. Mayjen Sutoyo}

14. Tree 1re distributed along west and east sides of road, road median, and at viaduct 
fly-over. The number of trees is 485 composting from 17 species, comprising 90 trees at west-side, 123 trees at road-median, 181 trees at east-side, and 91 trees at viaduct lot. Almost one-third of those trees were in bad condition.

Table 1. Trees Condition at Study Area of East Jakarta City

\begin{tabular}{|c|c|c|c|c|c|c|}
\hline \multirow{2}{*}{ No. } & \multirow{2}{*}{ Location } & \multicolumn{5}{|c|}{ Number of Tree Condition } \\
\hline & & total & best & good & bad & worse \\
\hline 1 & JI. Raya Bogor & 436 & 143 & 197 & 92 & 4 \\
\hline 2 & Jl. Mayjen Sutoyo & 495 & 192 & 126 & 167 & $=$ \\
\hline 3 & JI.A. Yani & 826 & 513 & 244 & 48 & 21 \\
\hline 4 & Jl. Kali Malang & 842 & 605 & 21 & 216 & - \\
\hline 5 & Jl. Raya Kayu Putih & 427 & 225 & 167 & 34 & 1 \\
\hline 6 & Taman Darmaga & 213 & 169 & 39 & 21 & 3 \\
\hline 7 & Taman Hutan Kota & 988 & 975 & 13 & -1 & - \\
\hline & Grand Total & 4227 & 2822 & 807 & 559 & 29 \\
\hline & & & $66,8 \%$ & $19,1 \%$ & $13,2 \%$ & $0,7 \%$ \\
\hline
\end{tabular}

\section{c. A. Yani Street}

Trees were distributed along west -sides of road in the north-south orientation from the point of Jatinegara fly-over to Pramuka intersection, and at east-side running to J1 Suprapto intersection. The number of trees is $\mathbf{8 8 2}$ composting from 15 species, comprising 359 trees at west-side and 523 trees at east-side. Almost one-third of those trees were in bad condition. Lest than $10 \%$ of trees at this site was in bad - worse condition.

\section{d. Kalimalang Street}

Trees were distributed along north and south sides of road, with the west-east orientation from the point of Cipinang Muara to Pasar Sumber Artha. The number of trees is 842 composting from 12 species, comprising 255 trees at north-side and 587 trees at southside. Among the trees, there was about one fourth in bad condition.

\section{e. Kayu Putih Raya Street}

Trees were distributed along west and east sides of road, road median, and west separator and east separator, with the north-south orientation from the point of Tanah Mas Kayu Putih intersection to Perintis Kemerdekaan intersection. The number of trees is 427 composting from 13 species, comprising 51 trees at west-side, 42 trees at west separator, 131 trees at road-median, 168 trees at east separator and 35 trees at east side. Almost one-third of those trees were in bad condition. Among the trees, lest than $10 \%$ was in bad condition.

\section{d. Dermaga Park}

The location of Dermaga Park is at Jl. Duren Sawit Raya. The Dermaga park was consisted of 11 lots, the lots varied in the size of area of 200 to $500 \mathrm{~m}^{2}$. The number of trees at Dermaga park is 213 involving 21 species. Most of the trees were in a best condition, and only a little was in bad to worse condition.

\section{e. Hutan Kota Park}

The location of Dermaga Park is at Jl. Dogol, Pondok Kelapa. The Dermaga park was consisted of 3 lots, the total area consisting 2 ha. The number of trees at Dermaga park is 988 involving 18 species, distributed as 381 trees at Lot-1, 317 trees at Lot-2, and 290 trees at Lot-3. All of the trees were in a good to best condition.

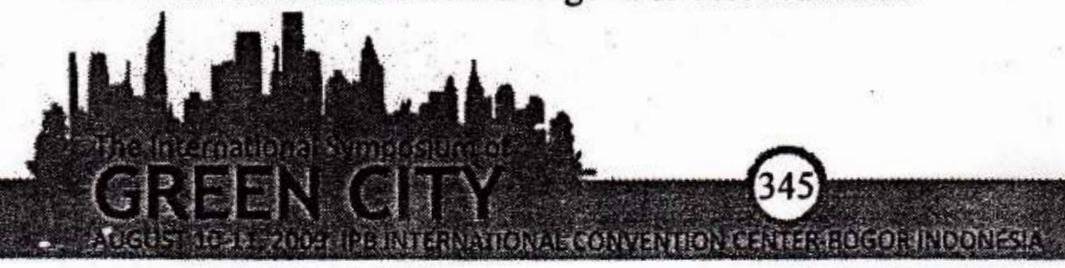




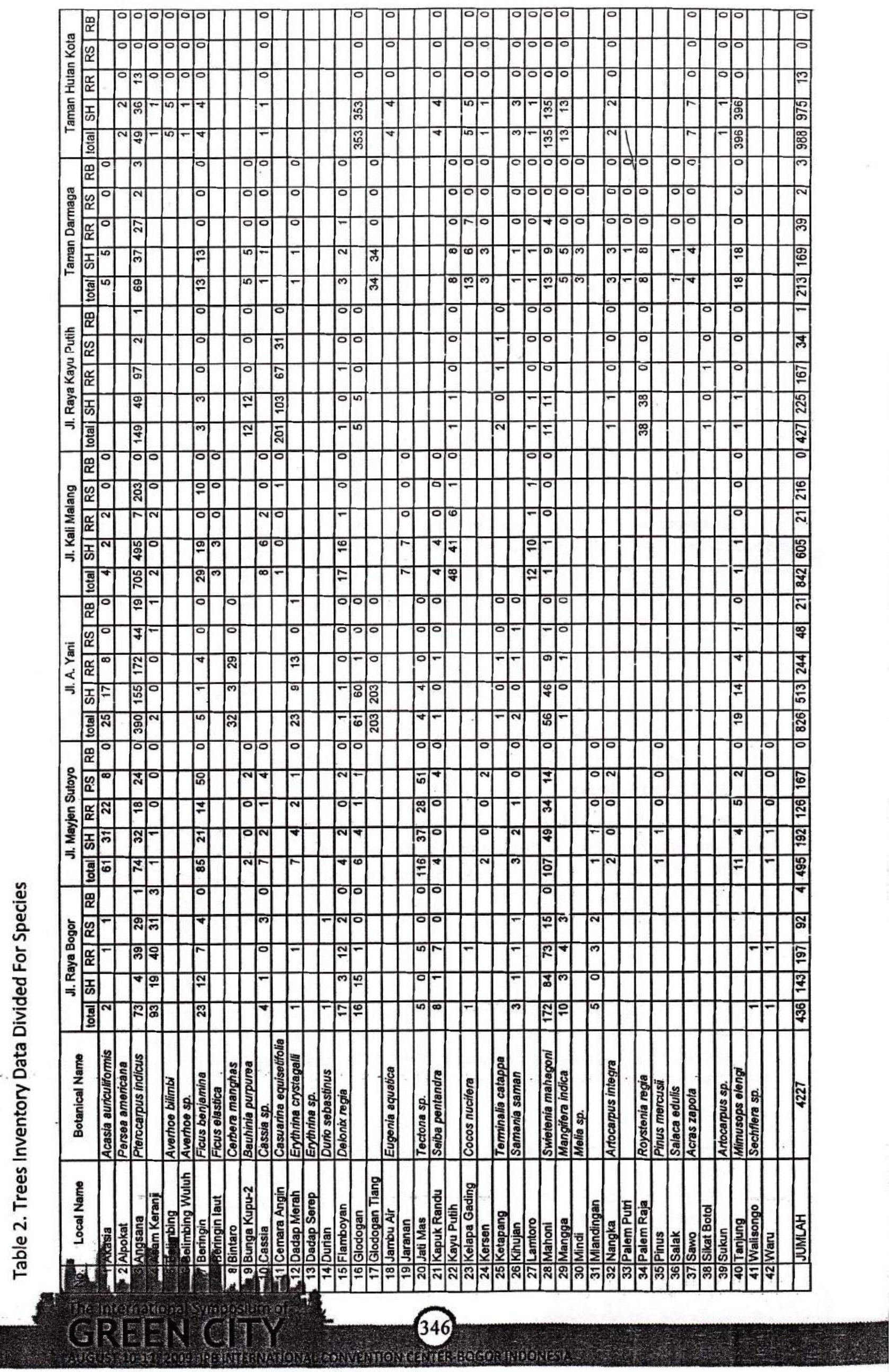




\section{THE BUILDING OF GEOGRAPHIC INFORMATION MANAGEMENT}

\section{a. Geographic Information Management}

The GIS of trees resulted from the observation was built up by using ArcView. User can retieve the location and condition of individual tree by opening this program. In order to get operation of this program, the user should procced some steps:

(1) Open the program of ArcView

(2) Activate all available extention tools

(3) From File menu/ Open Project/ select the project with the extention format *apr.

Figure 2 below shows the view of the project of GIS in retrieving trees located at specific road. User can aiso look up the directory of trees at spesific location, including the information of trees health condition.

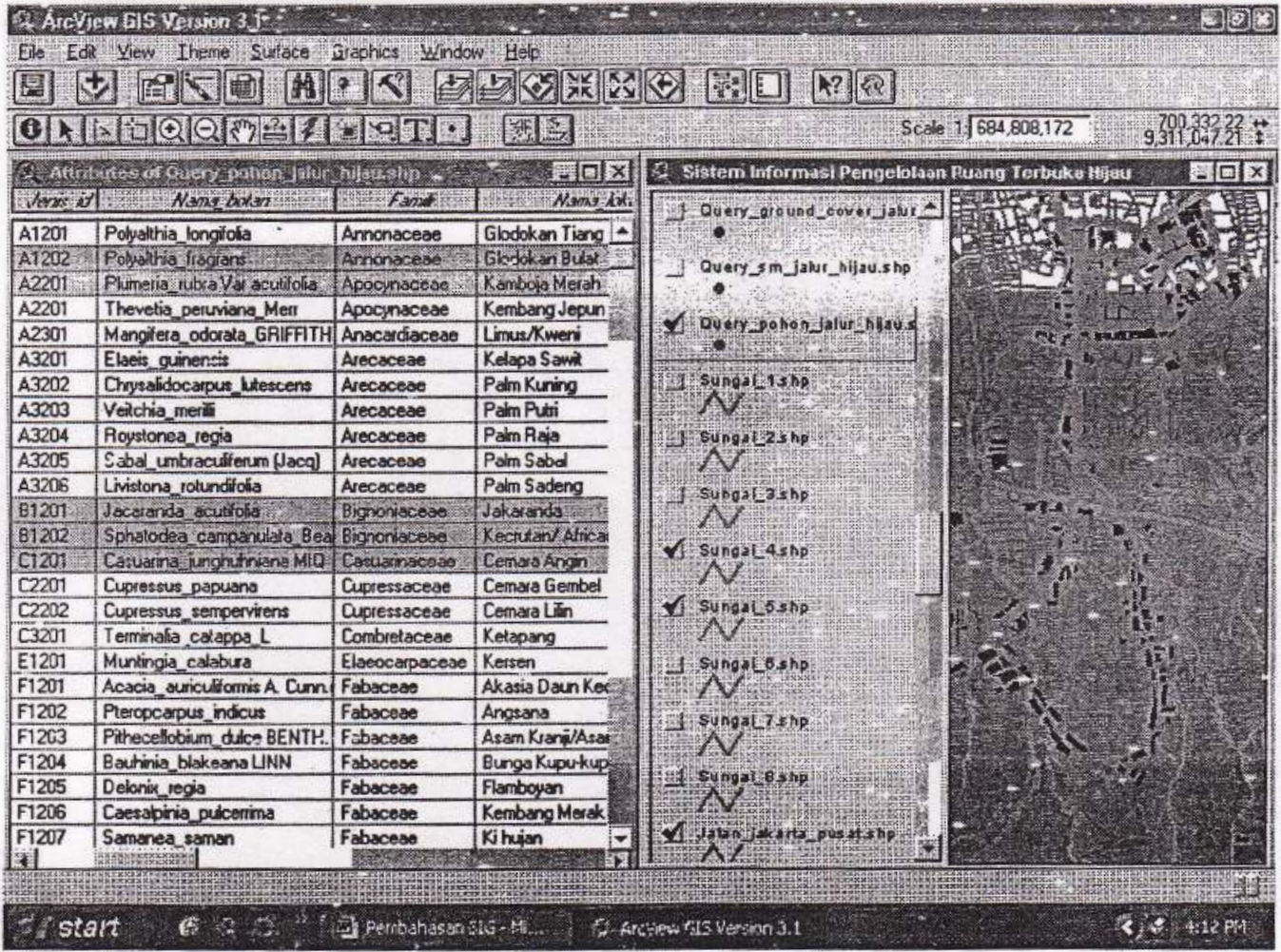

Figure 2. GIS for Trees Inventory Database of East Jakarta City, Indonesia
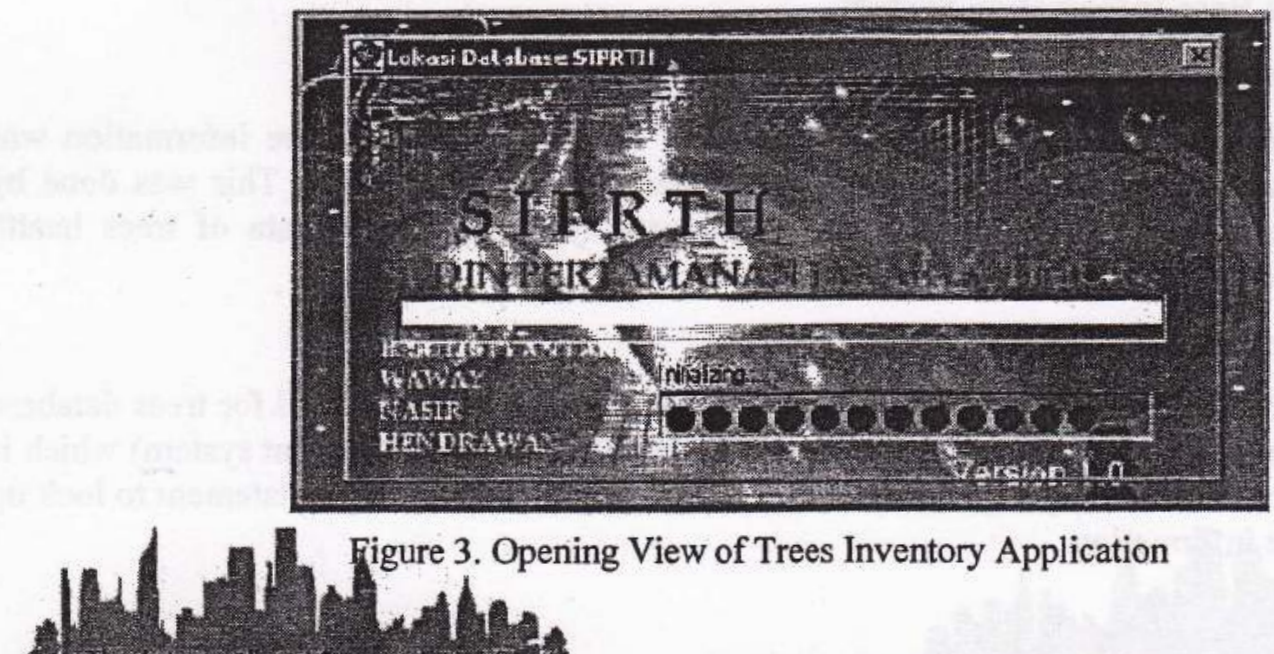


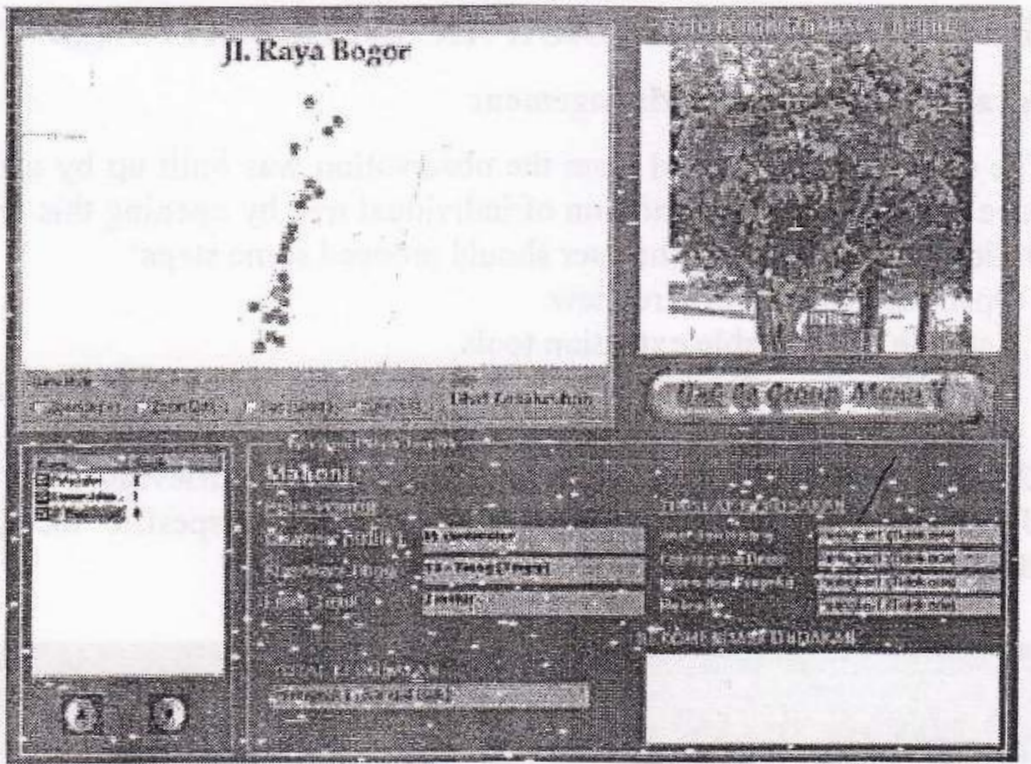

Figure 4. User interface for urban trees mangement

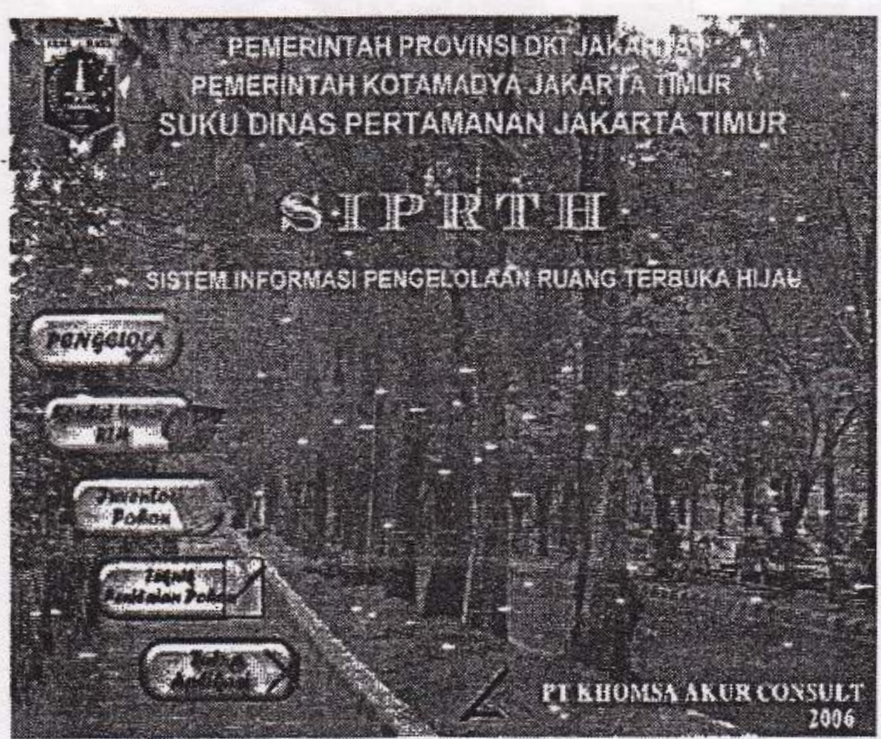

Figure 5. Retrieving information of individual tree at spesific location

\section{b. Object-Base Information System}

- Database and Database Management System

The database was designed in esay way for retrieving data. The information was divided into some tables, and every table stores specific entity. This was done by dividing the table for data of trees inventory and table for data of trees health valuation

- Access 2000 DBMS For Windows

MS Access is one of a good database application, was very useful for trees database management, because it containes of DBMS (database management system) which is facilitated with query. The query is very important for building a statement to look up the infill rmation. 
- Application of Database Management with MS Visual Basic 6.0

MS Visual Basic is a programming language working in the area of MS Windows, that is why MS Visual Basic can optimalize MS Windows. This language was successfully building up the application for trees database management. Even, the application can be built to retrieve image data in form of GIS. By making a user interface project using MS Visual Basic, a user can easily retieve the data and information within it. The illustrations below show views of user interface built up as MS Visual Basic project.

\section{CONCLUSION}

Urban trees condition in a form of database that comprises of huge number of trees can managed in a simple way, and can easily retrieve by user. By using the capacity of MS Visual Basic 6, the database of urban trees condition even can be retrieved as an information in form of GIS. This capacity could be used worldwide for all urban areas, due to evaluate the natural resourges in the cities.

\section{REFERENCES}

Alam, MAJ. 2005. Mengolah Database dengan SQL dan Microsoft Query dalam Microsoft Excel. Elex Media Komputindo Gramedia. Jakarta.

Arnold, H. F. 1980. Tree In Urban Design. Vand Nostrand Reinhold Co. Inc. New York. $168 \mathrm{p}$

Carpenter, P.L., T.D. Walker dan F.O. Lanphear. 1975. Plants in the Landscape. W.H. Freeman and Co. San Fransisco. 481p.

Davis, G., 1995. Kerangka Dasar Sistem Informasi Manajemen. PT. Pustaka Binama Pressindo. Jakarta. 68 p.

Grey, G.W. dan F.I. Deneke. 1986. Urban Forestry. John Wiley and Soris, Inc. New York.

Miller, R. W. 1988. Urban Forestry : Planning and Managing Urban Greenspace. Prentice Hall, Inc. New Jersey. 404 p

Pirone, P. P. 1972. Tree Maintenance. Oxford University Press. New York. 574 p.

Prahasta, E. 2002. Konsep-konsep Dasar Sistem Informasi Geografi. Penerbit Informatika. Bandung. 